Key Words:

Glass Beads

DWPF

Melter

Retention:

Permanent

\title{
DWPF GLASS BEADS AND GLASS FRIT TRANSPORT DEMONSTRATION
}

\author{
D. J. Adamson
}

B. R. Pickenheim

NOVEMBER 2008

Savannah River National Laboratory

Savannah River Nuclear Solutions

Aiken, SC 29808

Prepared for the U.S. Department of Energy Under

Contract Number DE-AC09-08SR22470 


\section{DISCLAIMER}

This work was prepared under an agreement with and funded by the U.S. Government. Neither the U. S. Government or its employees, nor any of its contractors, subcontractors or their employees, makes any express or implied:

1. warranty or assumes any legal liability for the accuracy, completeness, or for the use or results of such use of any information, product, or process disclosed; or

2. representation that such use or results of such use would not infringe privately owned rights; or

3. endorsement or recommendation of any specifically identified commercial product, process, or service.

Any views and opinions of authors expressed in this work do not necessarily state or reflect those of the United States Government, or its contractors, or subcontractors.

Printed in the United States of America

Prepared for

U.S. Department of Energy 
Key Words:

Glass Beads

DWPF

Melter

Retention:

Permanent

\title{
DWPF GLASS BEADS AND GLASS FRIT TRANSPORT DEMONSTRATION
}

\author{
D. J. Adamson
}

B. R. Pickenheim

NOVEMBER 2008

Savannah River National Laboratory

Savannah River Nuclear Solutions

Savannah River Site

Aiken, SC 29808 


\section{REVIEWS AND APPROVALS}

D. J. Adamson, Co-author, Environmental \& Chemical Process Technology Date

B. R. Pickenheim, Co-author, Environmental \& Chemical Process Technology Date

M. L. Restivo, Technical Review, Environmental \& Chemical Process Technology Date

B. J. Giddings, Manager, Engineering Development Laboratory

Date

C. C. Herman, Manager, SRNL DWPF Programs

Date

J. E. Occhipinti, Manager, Waste Solidification Engineering

Date

J. C. Griffin, Manager, Environmental \& Chemical Process Technology Research $\quad$ Date 


\section{TABLE OF CONTENTS}

LIST OF FIGURES .....................................................................................................

LIST OF TABLES.....................................................................................................................

LIST OF ACRONYMS ....................................................................................................................

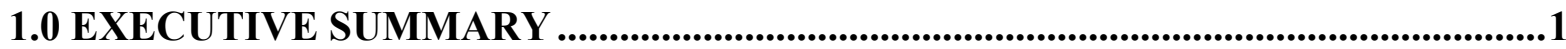

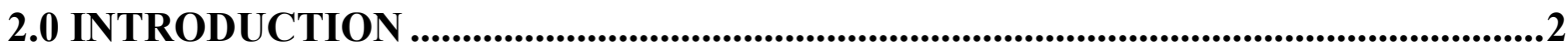

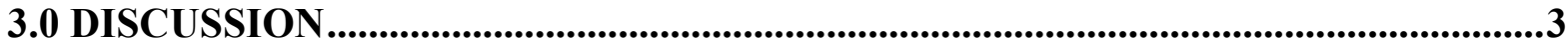

3.1 Experimental Approach and Setup.................................................................................

3.1.1 Test Results......................................................................................................................

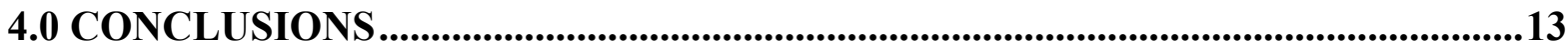

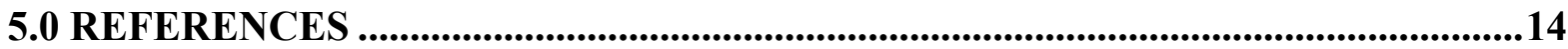

APPENDIX A. R \& D Direction For Conducting Conduction Glass Beads and Frit

Transfer. 15

6.0 Irritants - a chemical that can cause inflammation at the point of contact. .......................24 


\section{LIST OF FIGURES}

Figure 1. Drawing of DWPF Pilot-scale Frit Transfer Test System .................................4

Figure 2. Picture of DWPF Pilot-scale Frit Transfer Test System .....................................6

Figure 3. Glass Bead Slurry in Feed Tank .......................................................................8

Figure 4. Bead Slurry Transfer ...................................................................................................9

Figure 5. Beads Settled in Horizontal Pipe ............................................................................10

Figure 6. Solid Plug Created by Glass Bead Slurry in Vertical Line ................................11

Figure 7. Frit Slurry Transfer, Pump Pressure and Flow ......................................................12

\section{LIST OF TABLES}

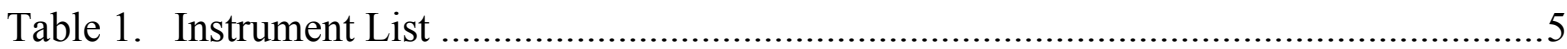




\title{
LIST OF ACRONYMS
}

\author{
DAS Data Acquisition System \\ DWPF Defense Waste Processing Facility \\ PVC Polyvinyl Chloride \\ SME Slurry Mix Evaporator \\ TTR Task Technical Request
}




\subsection{EXECUTIVE SUMMARY}

DWPF is considering replacing irregularly shaped glass frit with spherical glass beads in the Slurry Mix Evaporator (SME) process to decrease the yield stress of the melter feed (a nonNewtonian Bingham Plastic). Pilot-scale testing was conducted on spherical glass beads and glass frit to determine how well the glass beads would transfer when compared to the glass frit.

Process Engineering Development designed and constructed the test apparatus to aid in the understanding and impacts that spherical glass beads may have on the existing DWPF Frit Transfer System.

Testing was conducted to determine if the lines would plug with the glass beads and the glass frit slurry and what is required to unplug the lines. The flow loop consisted of vertical and horizontal runs of clear PVC piping, similar in geometry to the existing system.

Two different batches of glass slurry were tested: a batch of $50 \mathrm{wt} \%$ spherical glass beads and a batch of $50 \mathrm{wt} \%$ glass frit in process water. No chemicals such as formic acid was used in slurry, only water and glass formers. The glass beads used for this testing were commercially available borosilicate glass of mesh size $-100+200$. The glass frit was Frit 418 obtained from DWPF and is nominally $-45+200$ mesh.

The spherical glass beads did not have a negative impact on the frit transfer system. The transferring of the spherical glass beads was much easier than the glass frit. It was difficult to create a plug with glass bead slurry in the pilot transfer system. When a small plug occurred from setting overnight with the spherical glass beads, the plug was easy to displace using only the pump. In the case of creating a man made plug in a vertical line, by filling the line with spherical glass beads and allowing the slurry to settle for days, the plug was easy to remove by using flush water.

The glass frit proved to be much more difficult to transfer when compared to the spherical glass beads. The glass frit impacted the transfer system to the point that the test apparatus had to be disassembled to dislodge the plugs created in the system. 


\subsection{INTRODUCTION}

DWPF requested that SRNL evaluate the suitability of using spherical glass former (beads) versus the glass frit that is currently used in melter feed preparation at DWPF ${ }^{1}$. Bench-scale studies have shown that the use of spherical beads reduces the yield stress/consistency of Slurry Mix Evaporator (SME) product. This may allow for the processing of higher solids feeds for increased melt rate. The use of beads may also allow for easier recovery from process upsets such as stopped pumps or plugged lines from in the frit transfer system.

To satisfy the TTR, a pilot-scale glass frit transfer system was designed and built to study how well the spherical glass beads would transfer when compared to the glass frit. The material of construction was chosen to be clear PVC to visually witness the transport of the glass beads and frit.

The frit transport testing was conducted with a slurry of glass formers and water. This test was meant to simulate the frit slurry make-up system at DWPF, which does not include any waste in the DWPF process. Thus, no waste simulant was required or used in testing.

This work satisfies objective 1 of the Task Technical \& Quality Assurance Plan ${ }^{2}$ regarding feed system evaluation. The balance of the work will be completed at a later date in conjunction with the DWPF Lab Sampling and Method Improvement effort. 


\subsection{DISCUSSION}

\subsection{EXPERIMENTAL APPROACH AND SETUP.}

A pilot-scale Frit Transfer System was designed and constructed in 786-A per the drawing shown in Figure 1. The lines were made of clear PVC pipe to allow for visual study of the bead or frit slurry transfer. A few of the line couplings (tee, elbows, etc) and valves were CPVC and were not transparent. The vertical height of piping was 20 feet, extending above the second mezzanine. The length of the horizontal pipe on the first mezzanine was approximately 19 feet. The dimensions were chosen to mimic the hydraulic characteristics of the existing DWPF Frit Transfer System.

The slurry was pumped through the transfer system using a Wilden P8 diaphragm pump. The flow rate of the slurry was controlled by regulating the flow rate and pressure of air supplied to the diaphragm pump. The maximum supply pressure to the diaphragm pump was 125 psig.

The horizontal and vertical lines were constructed with back-flush ports. The back-flush ports would allow process water to be connected to back-flush the line in the case of a plugged line. A back-flush consisted of a piped-in tee, with a hose Bibb connection on the branch connection (when placed in a run) or tee connection (when used in place of an elbow) to allow the introduction of flush water.

The contents of the Feed Tank were agitated continuously during the bead/frit slurry transfer to keep the particles suspended. The test system was designed such that the bead/frit slurry would flow through either the horizontal section or the vertical section then flow back into the Feed Tank. Unlike DWPF where the frit is transferred once and dropped in the SME Tank, in this testing the spherical glass beads and the glass frit were cycled many times through the pilot-scale test system.

Observations during testing appeared to indicate that shearing in the pump and around the agitator impeller in the Feed Slurry Make-up Tank may be causing some breakage of some of the glass beads. This observation could not be objectively characterized. 


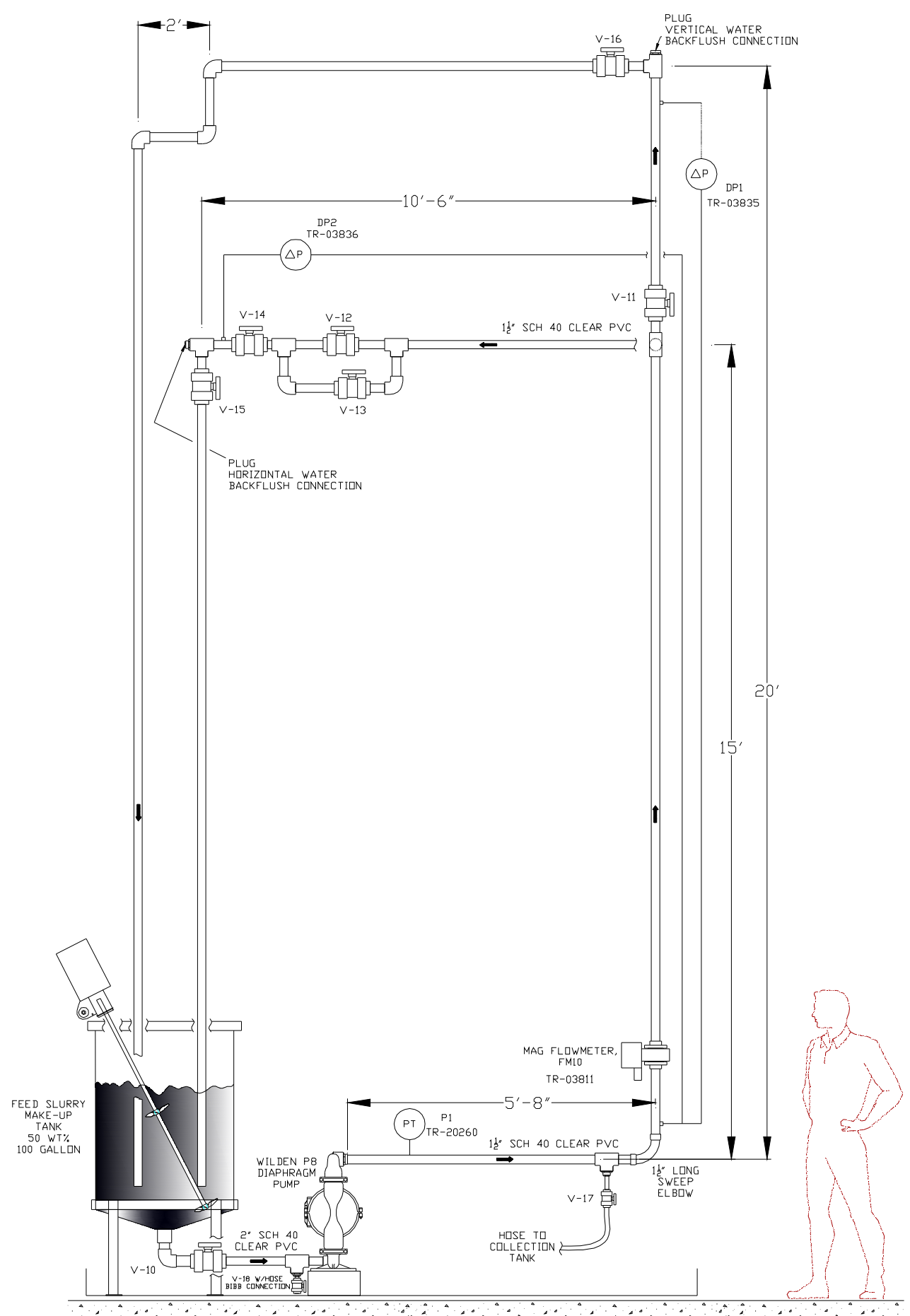

Figure 1. Drawing of DWPF Pilot-scale Frit Transfer Test System 
The piping was instrumented with two differential pressure transmitters to determine the differential pressure if a plugged line occurred. A pressure transmitter was installed to determine the pressure created by the transfer pump. The flow rate of the bead/frit slurry was monitored using a magnetic flow meter. The transmitter and flow meter signals were sent to a Data Acquisition System (DAS) where the test data was recorded. Table 1 provides an instrument list along with calibration information of the instruments.

Table 1. Instrument List

\begin{tabular}{|c|c|c|c|}
\hline M\&TE \# & Description & Calibration range & Uncertainty \\
\hline TR-03811 & $\begin{array}{c}\text { Magnetic Flow meter, ABB } \\
\text { Instrumentation Inc. }\end{array}$ & $0-100 \mathrm{GPM}$ & $\pm 0.57 \mathrm{GPM}$ \\
\hline TR-20260 & $\begin{array}{c}\text { Pressure Transmitter, } \\
\text { Rosemount }\end{array}$ & $0-200$ PSI & \pm 0.14 PSI \\
\hline TR-03835 & $\begin{array}{c}\text { Differential Pressure } \\
\text { Transmitter, Rosemount }\end{array}$ & $0-200$ PSI & \pm 0.19 PSI \\
\hline TR-03836 & $\begin{array}{c}\text { Differential Pressure } \\
\text { Transmitter, Rosemount }\end{array}$ & $0-200$ PSI & \pm 0.17 PSI \\
\hline
\end{tabular}

Testing was conducted per the R\&D Direction in Appendix A. Testing results were also recording in a Laboratory Notebook, WSRC-NB-2007-00098.

A picture of the pilot-scale system constructed in 786-A is shown in Figure 2. 


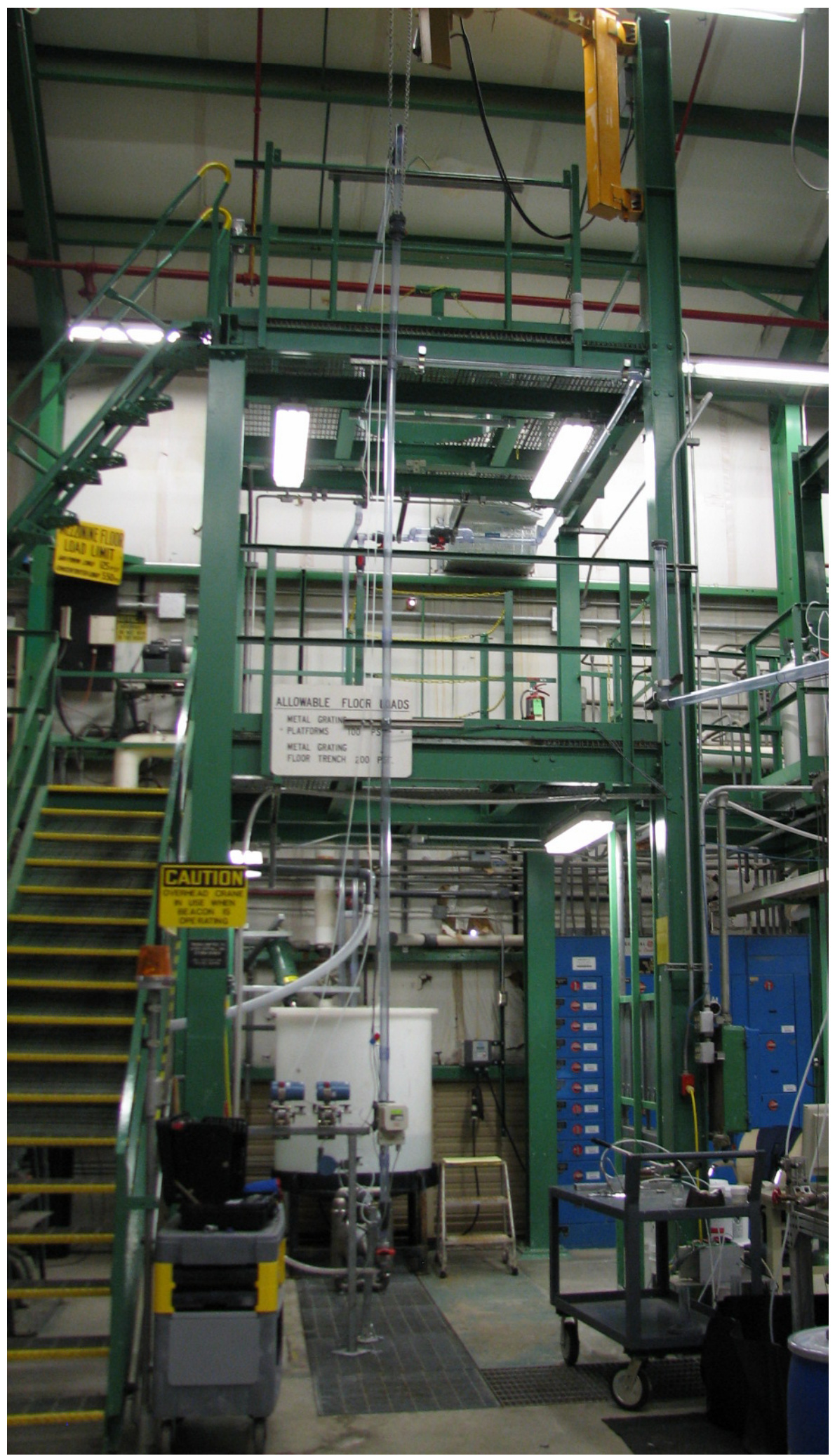

Figure 2. Picture of DWPF Pilot-scale Frit Transfer Test System 
The spherical glass beads used in the transfer testing came from Potters Incorporated in 5 gallon buckets. There were two different spherical glass bead batches, P-0060 and P-0040. The glass beads were mixed per the R\&D Instructions (see Appendix A) 250.63 Lbs of the P-0060 batch and 224.37 Lbs of the P-0040 batch spherical beads were slowly added to 57 gallons of water being agitated in the Feed Slurry Make-up Tank (see Figure 1). This mixture of glass beads and water created $50 \mathrm{wt} \%$ slurry. No chemicals such as formic acid was used in slurry, only water and glass beads.

Testing with the glass frit slurry was conducted in the same manner as the glass beads. 475 Lbs of glass frit was added to 57 gallons of water to obtain $50 \mathrm{wt} \%$ slurry. As with the glass bead slurry, no formic acid was added to the slurry, only water and glass frit. The glass frit was obtained from:

Ferro Corporation

Bin \# K028893H

Lot \# 510L2

Date loaded at Ferro 6/18/2007

\subsubsection{Test Results}

The transfer of the bead slurry through the system started as soon as the beads were added to the Feed Tank. The beads were transferred at various flow rates in an attempt to create conditions where a plug might form. The flow was stopped and started, allowing the beads to settle in the piping, thus possibly creating a plug. After numerous attempts, no plug was formed that could not be displaced by simply restarting the diaphragm pump.

Overnight, the diaphragm pump and the tank agitator were shut off, allowing the beads to settle out in the lines and in the Feed Tank. Figure 3 is a picture of the glass bead slurry settled inside the Feed Tank. Before starting a transfer the following morning, the contents of the tank were mixed well by using an air sparger to aid in mixing before turning on the agitator, thus preventing damage to the agitator blades. 


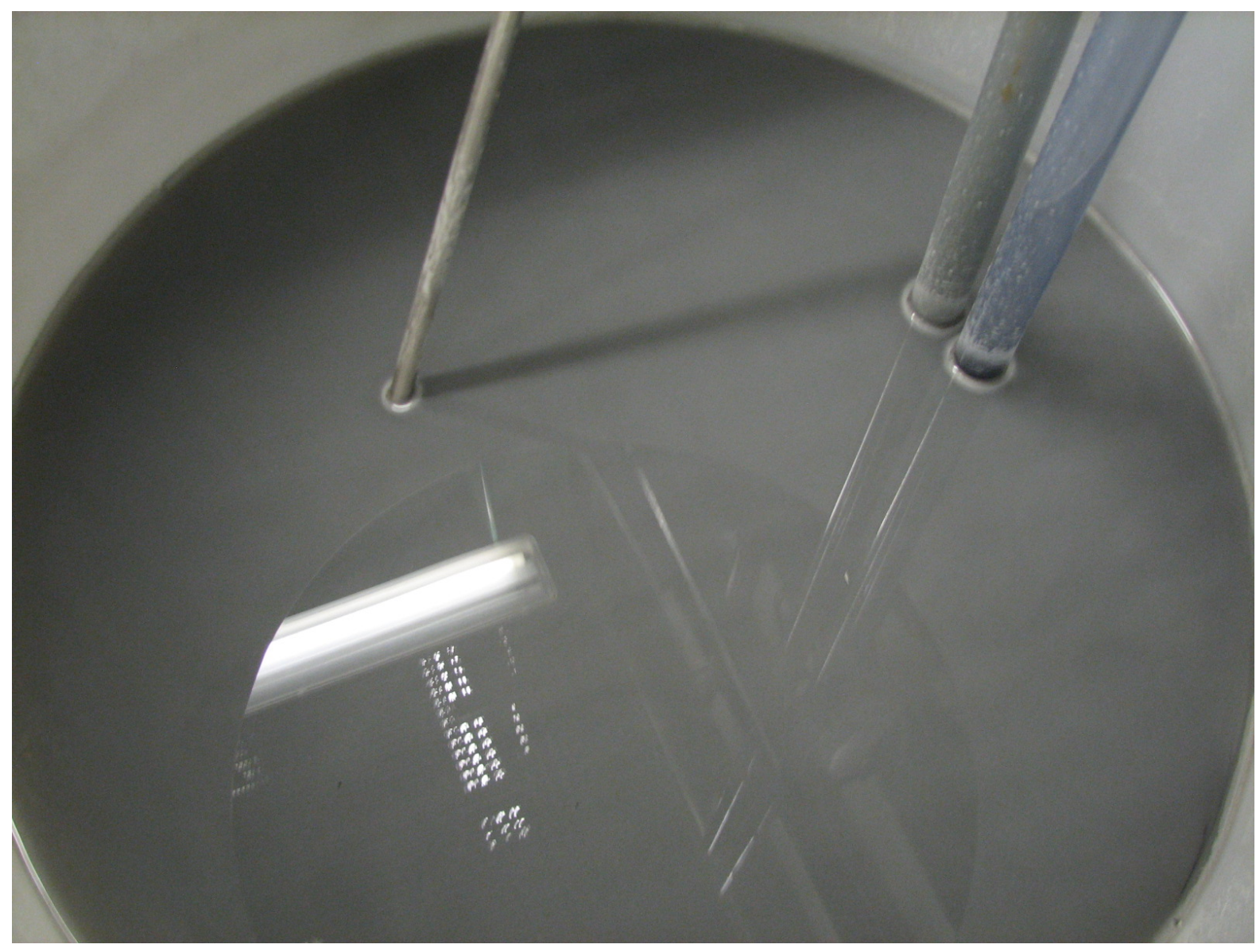

\section{Figure 3. Glass Bead Slurry in Feed Tank}

Once the bead slurry in the tank was well mixed, the transfer pump was turned on. The spherical glass beads that settled out in the lines were displaced using only the transfer pump.

Work continued on creating a plug in the transfer lines when pumping the bead slurry. The transfer was stopped by turning off the pump (flow drops to $0 \mathrm{GPM}$ ) for approximately 30 minutes to allow the glass beads to settle out as depicted in Figure 4. Each time, the settled bead slurry was easily displaced by restarting the transfer pump. 


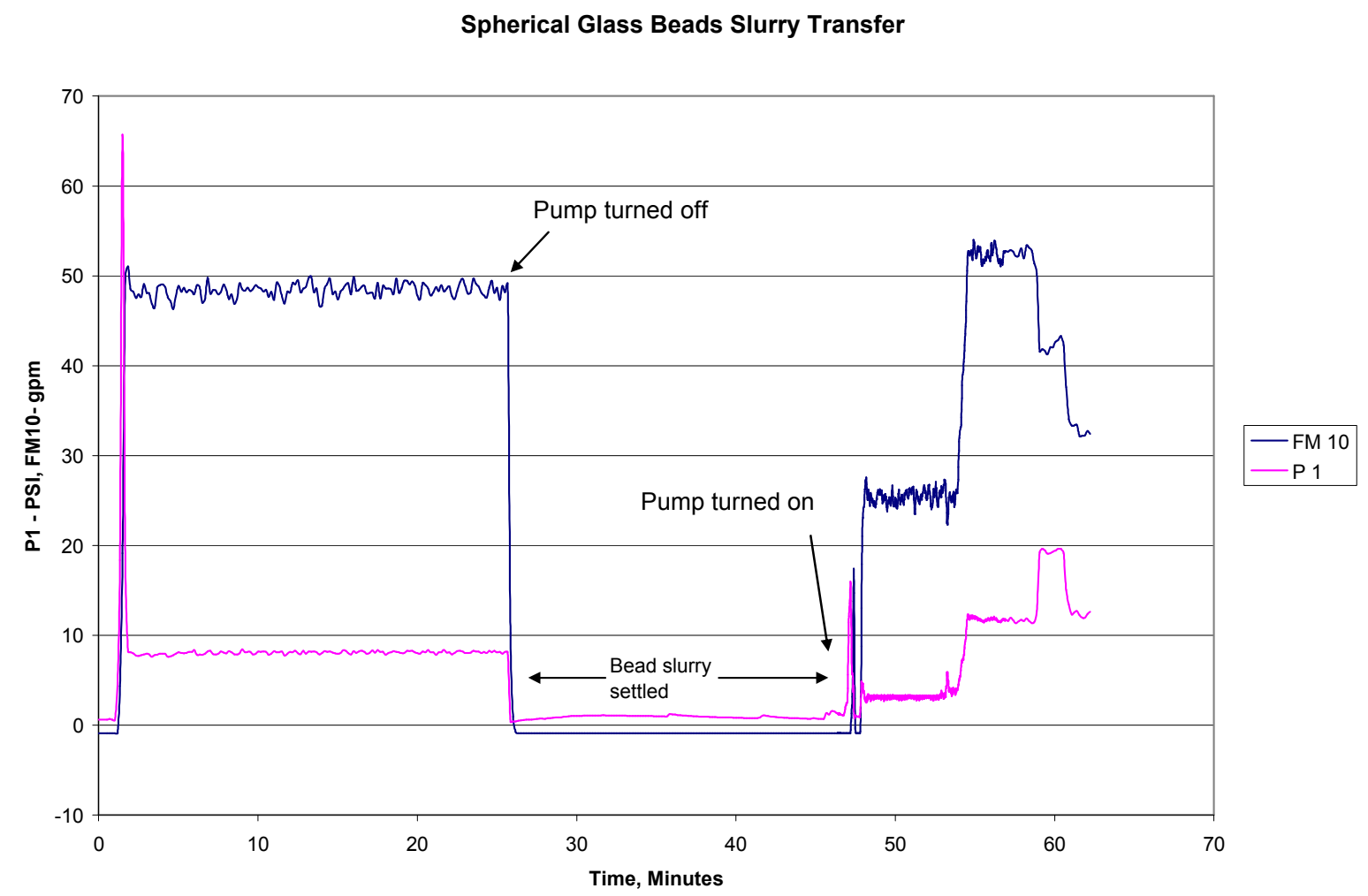

\section{Figure 4. Bead Slurry Transfer}

This method of trying to plug the transfer line with the bead slurry was attempted numerous times. Each time the pump was able to displace the settled spherical beads creating a plot similar to Figure 4.

When transferring through the horizontal line, V-12 was closed to force the flow of the bead slurry through the by-pass, forcing the beads to encounter a significantly higher flow resistance to precipitate pluggage. V-14 was also partially closed during the transfer in an attempt to create a plug in the vertical line. The transfer pump was then shut off for approximately 1.5 hours to allow the glass beads in the vertical lines to settle out as shown in Figure 5. 


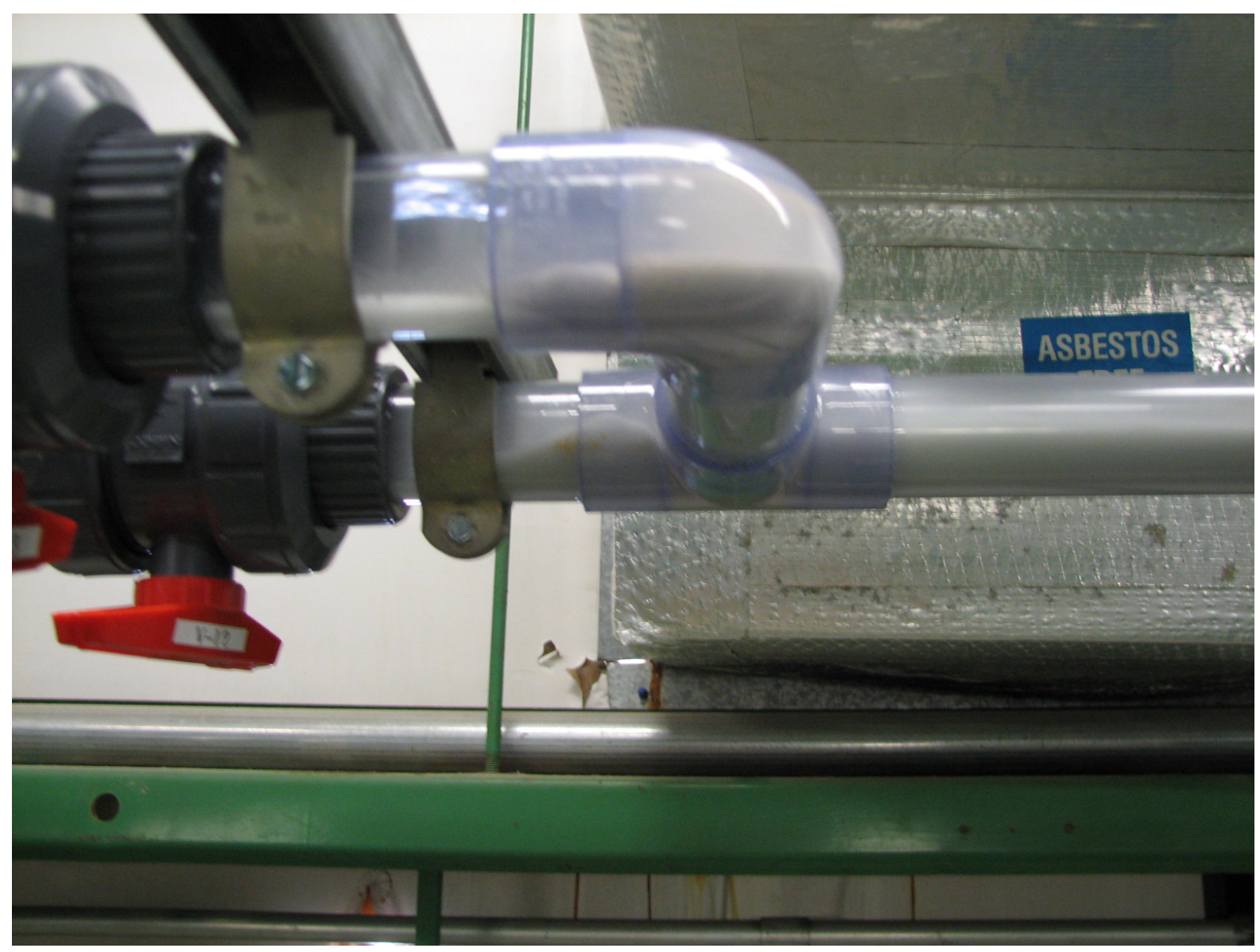

\section{Figure 5. Beads Settled in Horizontal Pipe}

When the transfer pump was restarted, the settled glass beads were displaced.

In an attempt to make a man-made plug in the vertical line, glass beads were added to the vertical line by pouring the beads through the vertical water backflush connection (see Figure 1). After filling the vertical line with glass beads, the beads were allowed to settle for approximately four days.

Figure 6 shows a solid plug in the clear PVC line. Note the water and glass bead interface after settling for many hours. 


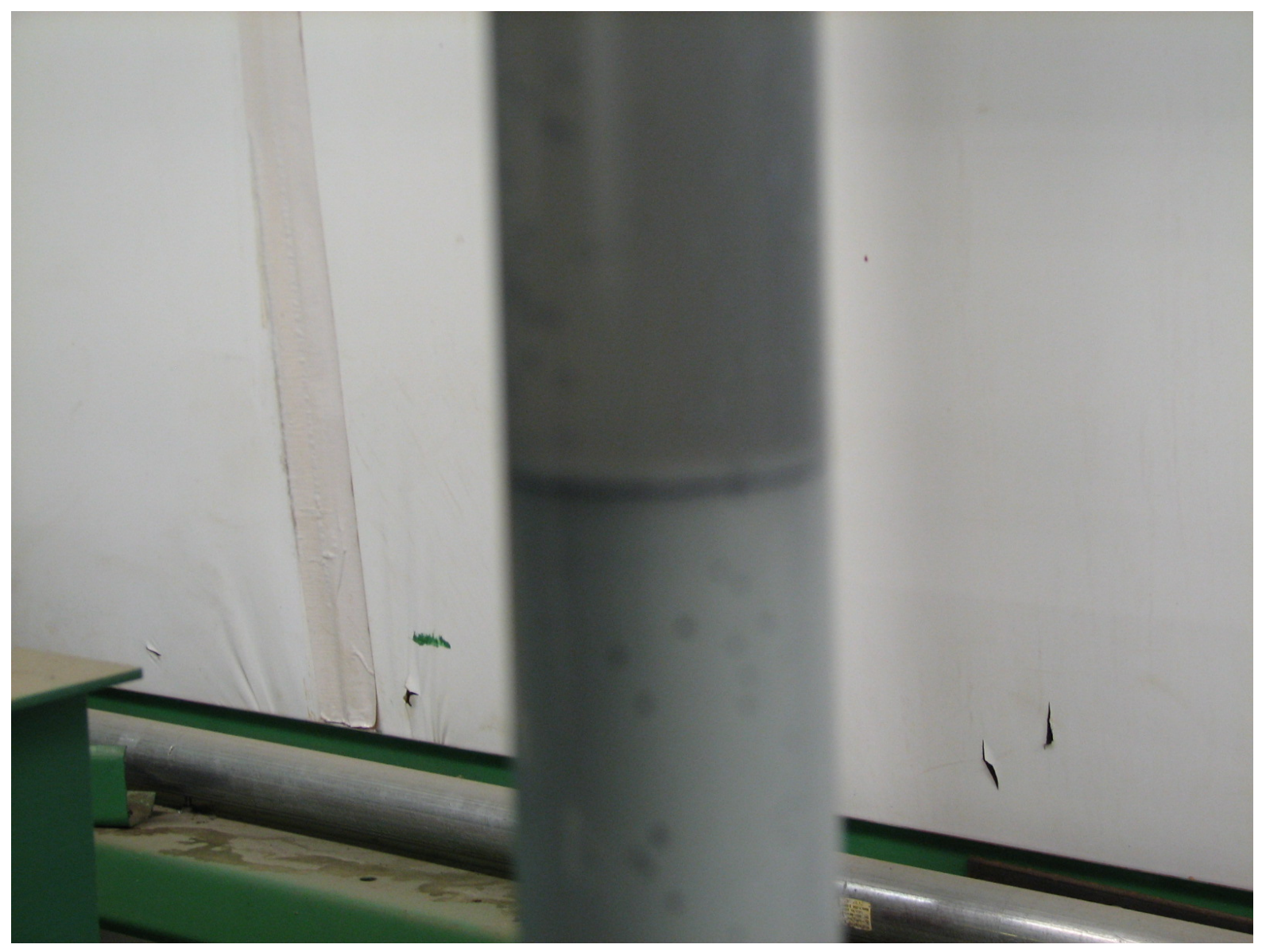

\section{Figure 6. Solid Plug Created by Glass Bead Slurry in Vertical Line}

After four days of setting, the transfer pump was started. The pump was unable to displace the plug created. However when process water was connected at V-17, the plug in the vertical line was easily flushed out. When restarting the transfer pump after the vertical plug had been flushed away, the pump still would not cycle. Further investigation showed that the glass beads had settled out in the diaphragms of the pump preventing it from cycling. When the process water was connected to V-18, the plug in the pump was flushed away. The pump could only be cleared in the direction of normal flow for the pump. The plug in the pump could not be cleared by back flushing due to the manufacturer's design of the pump.

After many hours of cycling the same glass spherical beads, the beads may have been acting more like glass frit. The beads were most likely broken-down due to the bead slurry being pumped through the system many times and being mixed vigorously in the Feed Tank.

Testing with the glass frit slurry was conducted in the same manner as the glass beads, where 475 Lbs of glass frit was added to 57 gallons of water in the Feed Tank to obtain $50 \mathrm{wt} \%$ slurry. The initial startup of transferring the frit slurry went well. The frit slurry was pumped through the system at flows ranging from about 36 GPM to 90 GPM for about one 
hour with no indication of creating a plug in the line. The pump was shut off for approximately two hours to allow the frit slurry to settle as depicted in Figure 7. Upon restarting the transfer pump, the pump would not cycle and the pressure produced by the pump was over 110 PSI. The transfer pump was unable to cycle because the plug in the line did not allow any movement of the frit slurry. Thus the transfer pump was unable to displace the plug in the vertical line.

Frit Slurry Transfer, Pressure \& Flow

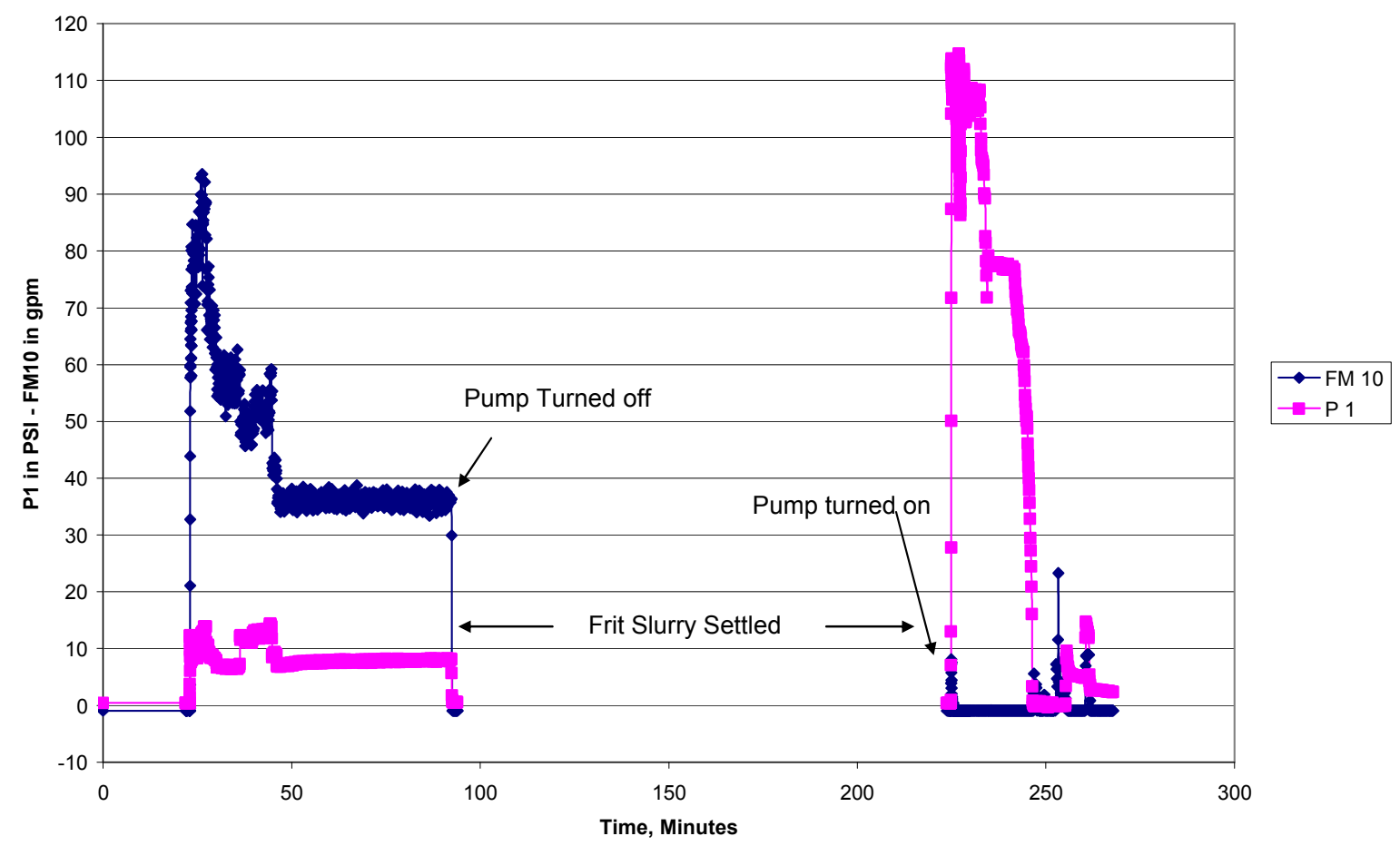

Figure 7. Frit Slurry Transfer, Pump Pressure and Flow

Process water was then hooked up at V-17 (see Figure 1). The 90 psig water pressure would not dislodge the frit slurry plug when flushing in the direction of flow. When the process water was hooked up to the Vertical Back-flush Connection, the frit slurry was back-flushed out of the vertical line at V-17. The pump remained plugged. Process water connected to V18 would not remove the plug in the pump due to not being able to close V-10. The glass frit had wedged the valve open making it impossible to close. With V-10 unable to be closed, water flowed into the tank not allowing the pump to be flushed out in the direction of normal flow. To remove the plug in the diaphragm pump, the frit slurry had to be removed from the Feed Tank and the pump disassembled. No additional transfers were made with the frit slurry. 


\subsection{CONCLUSIONS}

The spherical glass bead testing demonstrated that the beads transfer well with no indications that this geometry of frit would cause the existing Frit Transfer System at DWPF negative impacts. Testing suggested that transferring the spherical glass bead was much easier than the glass frit. No chemicals such as formic acid was used in the glass slurry, only water and glass formers. Also, testing suggested that less wear would occur to equipment (tanks, piping, pumps, valves, etc.) with the spherical glass beads when compared to the current DWPF frit.

The first and only transfer attempted with the frit proved to be much more difficult when compared to transferring the spherical glass beads. The frit impacted the transfer system to the point the Feed Tank had to be emptied and the pump disassembled to dislodge the plugs created in the system. 
SRNL-STI-2008-00412, REVISION 0

\subsection{REFERENCES}

1 Davis, B.A., 2007, Technical Task Request, Document No. : HLW-DWPF-TTR2007-0011

2 Pickenheim, B.R., 2007, Task Technical \& QA Plan, Document No. : WSRC-RP2007-00199 


\section{APPENDIX A. R \& D Direction For Conducting Conduction Glass Beads and Frit Transfer}

Prepared by:

D. J. Adamson
Date
Technical Review by:

\subsection{PURPOSE}

As part of the Technical Task Request [6.1], this R\&D Direction will evaluate the suitability of using spherical glass former (beads) in DWPF versus the glass frit that is currently used. Results have shown that the use of spherical beads reduces the yield stress/consistency of Slurry Mixed Evaporator (SME) product. This may allow for the processing of higher solids feeds for increased melt rate. Also will allow for easier recovery from process upsets such as stopped pumps or plugged lines. This Direction shall be appended to the final report for permanent documentation.

\subsection{SCOPE}

These directions, developed under the guidance of SRNL Conduct of R\&D [6.2] and of Procedure L1 [6.3], applies only to the setting up, testing, and dismantling of the frit transport system and the Hydragard sampling test system. The testing will be conducted in the Process Engineering Development Laboratory (PEDL), SRS Bldg. 786-A. To satisfy the TTR, a scaled glass frit transfer system will be built to determine if the spherical glass beads cause the transfer system to plug. It should be noted that the frit transport test will be conducted with a slurry of glass beads and water. This test is meant to simulate the frit slurry make-up system at DWPF. At this point in the DWPF system there is no waste involved in the transport of the frit. Also a $1 / 240^{\text {th }}$ scaled Hydragard test loop will be constructed to perform a series of mixing and sampling test using a slurry of spherical glass beads and simulated waste.

\subsection{Definitions and Abbreviations -}

$\mathrm{N} / \mathrm{A}$

2.2 Responsibilities

2.2.1 D. J. Adamson - Principal Investigator on pilot testing at PEDL and is responsible to carry out requirements of the Task Technical \& QA Plan (TTP) [WSRC-RP-2007-00199] [6.1] to include the design of the overall test, development of this procedure, have ready the test equipment, analyze the experimental data, and report the results.

2.2.2 M. L. Restivo - SRNL Design Engineer and is responsible to design the test equipment and supervise equipment fabrication when needed.

2.2.3 D. B. Burns - SRNL Immediate Manager

2.2.4 B. R. Pickenheim - SRNL Project Lead, "Use of Beads to Replace Frit in DWPF" 
All SRNL personnel located at the test site shall follow all safety rules and regulations of the Process Engineering Development Laboratory (PEDL) and shall have facility specific training. The appropriate PPE shall be used at all times. During any mixing of the alkaline simulants a minimum of a face shield, chemical resistance or nitrile gloves and lab coat shall be worn. During test operation a minimum of goggles, gloves, and lab coats will be worn while inside any secondary containment.

4.0

\section{PREREQUISITE ACTIONS}

\subsection{Simulant Preparation}

- $\quad$ Spherical glass beads will be provided by vendor

- $\quad$ Frit will be supplied by B. Pickenheim

- $\quad$ Simulant will be provided by B. Pickenheim

Note: As discussed in the approved EEC, the simulant will not be disposed of at the ending of the Hydragard testing. Additional testing may be required within SRNL. For hazards identification of the Hydragard simulant, see Appendix A4.

\subsection{Simulant Preparation}

For the frit transport line plugging test, no simulant is required. Only process water and glass frit or glass spherical beads are required.

A separate R\&D Direction will be used to prepare the simulant developed to match the DWPF feed. The simulant to be used with the glass frit and glass spherical beads will be provided by B. Pickenheim for the sampling test loop.

\subsection{Calibrations}

Instrumentation will be calibrated before and after testing using site standards.

\subsection{Test Rig Shakedown}

Conduct shakedown using only process water to ensure that all components, instrumentation is operating properly. Circulate water at $50 \mathrm{gpm}$. Inspect tanks, piping and valves for leaks. Operate the DAS to record data. Verify that the mixer, pump, flowmeter and pressure gages operate correctly. Replace any malfunctioning component and retest the system. Record all results in the Lab notebook [6.6].

4.5 Training

RW333P Training is required for this task.

\subsection{PERFORMANCE}

\subsection{General Information}

\section{Test Operation}

The testing will consist of three different parts. 
SRNL-STI-2008-00412, REVISION 0

- $\quad$ Pumping a $50 \mathrm{wt} \%$ slurry of spherical beads and process water solution up a vertical pipe to determine if the pipe will plug. This test will be followed by the same test with a slurry of glass frit and water. If the pipe plugs, determine what steps are required to unplug the line.

- $\quad$ Pumping a $50 \mathrm{wt} \%$ slurry of spherical beads and process water solution in a horizontal pipe to determine if the pipe will plug. This test will be followed by the same test with a slurry of glass frit and water. If the horizontal pipe plugs, determine what steps are required to unplug the line.

- $\quad$ Determine if the Hydragard is capable of obtaining samples that are compositionally representative of the process tank contents when using a slurry of spherical glass beads and simulated waste. The composition of Hydragard samples will be compared to grab samples taken from the process tank.

5.2.1 Determine if vertical line can be restricted of flow and unplugged.

5.2.1.1 Add 57 gallons of process water to the supply tank, see Appendix A1 for sketch of system .Agitate the contents of the tank and add $475 \mathrm{lb}$. of glass beads to form a 50 wt $\%$ slurry.

5.2.1.2 Start the DAS Computer and related equipment. Allow the equipment to warm up for at least 15 minutes:

5.2.1.3 Open V-10, V-11 and V-16. Close V-12, V-13 and V-15. Start pump and set flow rate to approximately $50 \mathrm{gpm}$. Adjust the flowrate at the direction of the PI. Allow solution to flow through system for 30 minutes or longer at the direction of the PI. Determine if any flow restrictions occurred. Note information in the lab notebook.

5.2.1.4 To create a plugged line, stop the flow to allow a plug to form in the line. It may require minutes for the beads to settle Attempt to restart the flow and observe whether the settled beads are swept from the line. Repeat as directed by the PI.

5.2.1.5 If a restriction occurs, first try to unplug the restriction using only the pressure of the pump. Second, unplug the restriction via connect a process water line to the Water vertical backflush connection, close V-10 and V-16. Open V-17 and turn on process water. If water backflushing is unable to remove the restriction, contact the PI.

5.2.1.6 Once the plug is removed, repeated 5.2.1.2 - 5.2.1.5 to plug the line. The plugging and unplugging of the line may be repeated 5 times at the direction of the PI.

Note: At the direction of the PI, spherical beads may be poured into vertical line to aid in forming a restricted line

\subsubsection{Determine if the Horizontal line can be restricted of flow and unplugged}

5.2.2.1 Use the same slurry in the supply tank that was used for the vertical plugging test. Agitate the contents of the tank.

5.2.2.2 Ensure the DAS computer and related equipment is on and has allowed to warm up for at least 15 minutes.

5.2.2.3 Open V-10, V-12, V-14 and V-15. Close V-11 and V-13. Start the diaphragm pump and set flow rate to $50 \mathrm{gpm}$. The flowrate may be adjusted at the direction of the PI. Allow the solution to flow through system for 30 minutes or longer at the direction of 


\section{SRNL-STI-2008-00412, REVISION 0}

the PI. Determine if any flow restrictions occurred in the horizontal line. Note information in the lab notebook.

5.2.2.4 To create a plugged line, first stop the pump until a plug forms in the line at the direction of the PI. Second, close valve V-12 and open V-13. Adjust V-14 to approximately half way closed, and run pump for 30 minutes. Valves may be adjusted per the PI to create a plug in the horizontal line. When using the spherical glass beads a restriction in the line may not be created.

5.2.2.5 If a restriction occurs, first try to unplug the restriction using only the pressure of the pump. Second unplug the restriction via connecting a water line to the Horizontal Water backflush connection. Close V-10 and V-15. Open V-17 and turn on process water. If back flushing is unable to remove the restriction, contact the PI.

5.2.2.6 Once the plug is removed, repeat 5.2.2.2 - 5.2.2.5 to plug the line. The plugging and unplugging of the horizontal line may be repeated 5 times at the direction of the $\mathrm{Pl}$.

5.2.2.7 Once the spherical glass beads plugging of the horizontal line testing is completed, remove process water and spherical beads from the supply tank. Save beads for further inspection.

Note: Line plug testing is complete at 5.2.2.6 using glass frit.

5.2.2.8 Clean supply tank and add 50 gallons of clean process water to tank.

5.2.2.9 Flush all lines to remove any remaining glass beads by running the transfer pump for approximately 15 minutes.

5.2.2.10 Remove the glass beads from the loop either by using a separate pump to clean the slurry tank or by using V-17 to pump the contents to a storage tank.

5.2.2.11 Remove process water from the supply tank and ensure tank is clean.

5.2.2.12 Add 57 gallons of process water to the supply tank, (see Appendix A1 for sketch of system). Agitate the contents of the tank and add $475 \mathrm{lb}$. of glass frit to form a 50 wt $\%$ slurry.

5.2.2.13 Repeat steps 5.2.1.1 through 5.2.2.9 with the slurry of glass frit and water.

5.2.2.14 Remove the glass frit from the loop either by using a separate pump to clean the slurry tank or by using V-17 to pump the contents to a storage tank.

\subsubsection{Hydragard Sampling Test using Spherical Beads}

5.2.3.1 Add 22 gallons of simulant to the SME tank; see Appendix A2 for sketch of system. The simulant will contain $50 \mathrm{wt} \%$ of total solids, of which $15 \%$ is spherical glass beads. $35 \%$ of the solids comes from the sludge itself. Do not add any rinse water to the SME tank.

5.2.3.2 Ensure the DAS Computer and related equipment is on and has warmed up for at least 15 minutes. Start logging at once per 10 seconds with the DAS.

5.2.3.3 Agitate the contents of the tank at $440 \mathrm{rpm}$ (representative of DWPF mixing conditions) for approximately 15 minutes or until thoroughly mixed.

5.2.3.4 Obtain three (3) approximately $15 \mathrm{ml}$ samples of the tank using a coliwasa. The sample location should be mid height of the slurry and approximately at the midpoint between the coils and the tank wall. Record sample \# and sample ID in the table located in Appendix A3.

5.2.3.5 Close BV4. Open BV1, BV2 and BV3 and turn on the circulation pump. Set the circulation to $33 \mathrm{gpm}$ on FM1. This corresponds to a velocity of $6 \mathrm{ft} / \mathrm{s}$ in the 1.5 " line. 
SRNL-STI-2008-00412, REVISION 0

5.2.3.6 Open BV4 to allow flow through the $3 / 4$ " transfer line. Adjust BV3 and BV4 to yield 4 , 6,8 , and $10 \mathrm{gpm}$ as indicated by FM2. Initially set the flow at $4 \mathrm{gpm}$. The total flow from the pump will be FM1 plus FM2 outputs. The combined flow will be approximately $33 \mathrm{GPM}$. The range of the total flow rate should remain between 32 $-34 \mathrm{gpm}$.

5.2.3.7 Obtain five (5) Hydragard samples in peanut vials for lab analyses. Also obtain three (3) grab samples using the Coliwasa under these conditions. Record sample \# and sample identification (ID) in the table located in Appendix A3.

5.2.3.8 Repeat three (3) Coliwasa and five (5) Hydragard samples at transfer line flow rates of 6, 8 and $10 \mathrm{gpm}$. Record sample \# and sample ID in the table located in Appendix A3. Include this table in the Lab notebook.

5.2.3.9 Remove simulant from SME tank and return simulant to storage drum. Do not discard simulant; the simulant will be used in a future task.

5.2.3.10 Rinse SME tank and flush lines with clean water. Place spent rinse water into a tote. (Ensure rinse water is not mixed with simulant).

5.2.3.11 Add 22 gallons of simulant to the SME tank. The simulant will contain $50 \mathrm{wt} \%$ of total solids, of which $15 \%$ is glass frit. $35 \%$ of the solids come from the sludge itself. Do not add any rinse water to the SME tank.

5.2.3.12 Repeat steps 5.2.3.1 through 5.2.3.12.

\subsubsection{Test End}

\subsection{REFERENCES}

6.1 Pickenheim, B.R., 2007, Task Technical \& QA Plan, Document No. : WSRC-RP-2007-00199, Rev. 0, June

6.2 Conduct of Research \& Development: Integrated Safety Management for the R\&D Environment, Document No. WSRC-IM-97-00024, Rev. 3.3, January 25, 2007.

6.3 SRNL Procedural Manual L1, April 25, 2007.

6.4 Qureshi, Z.H., Mixing And Sampling of Sludge-Frit-CST Slurries, Document No. WSRC-TR99-00309, Rev. 0, September, 1999.

6.5 Steimke, J.L., Testing of Hydragard Sampling System with Vial Inserts, Document No. WSRC-TR-97-0218, July 1997.

6.6 Task Notebook, "Spherical Glass beads testing in DWPF Pilot scale Frit Transfer and Hydragard Sampling Systems” Document No. WSRC-NB-2007-00098, June, 2007. 
SRNL-STI-2008-00412, REVISION 0

Appendices

Appendix A1: Schematic of Frit Transfer Line Plugging Test Setup

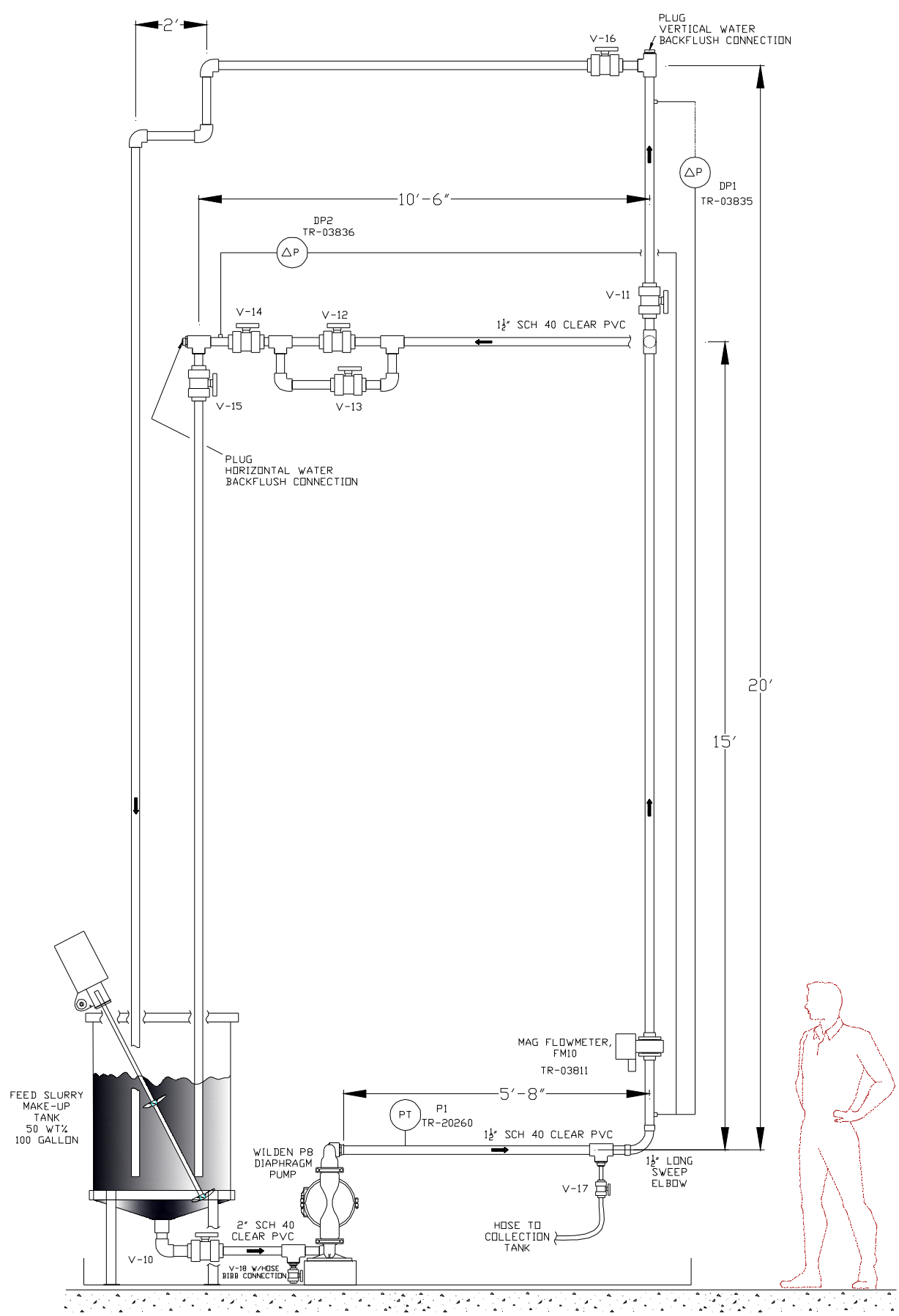

Page 20 of 25 
SRNL-STI-2008-00412, REVISION 0

Appendix A2: Schematic of Hydragard Sampling using Spherical Glass Beads

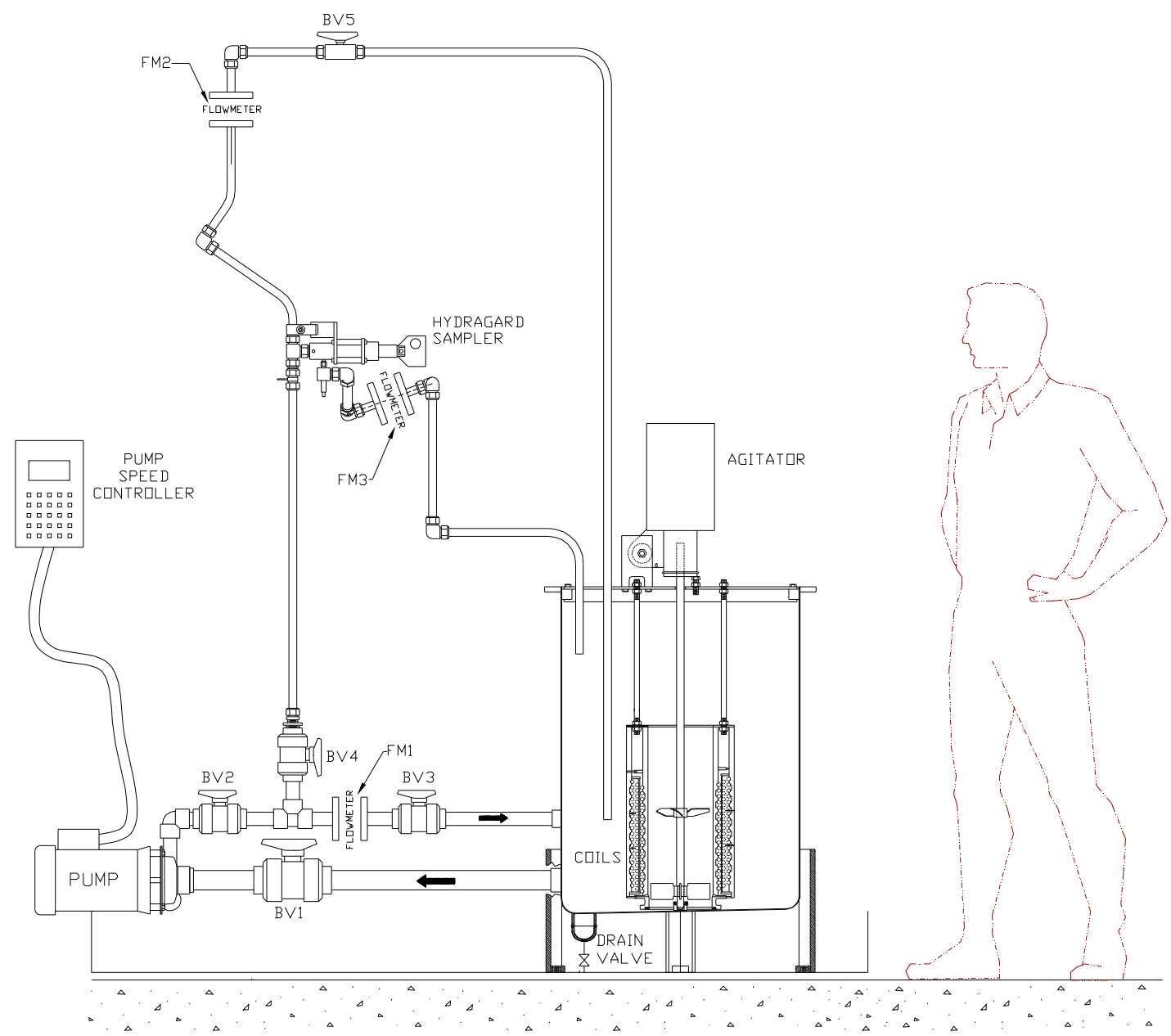

Page 21 of 25 
SRNL-STI-2008-00412, REVISION 0

Appendix A3: Sampling plan

\begin{tabular}{|c|c|c|c|}
\hline $\begin{array}{c}\text { Sample Line Flow, FM2 } \\
\text { GPM }\end{array}$ & $\begin{array}{l}\text { Hydragard Samples Peanut Vials } \\
\text { Sample \# and ID }\end{array}$ & $\begin{array}{c}\text { Grab Sample from } \\
\text { Tank } \\
\text { Sample \# and ID }\end{array}$ & $\begin{array}{l}\text { Hydragard Flow } \\
\text { GPM }\end{array}$ \\
\hline $\begin{array}{c}0 \\
\text { Baseline sample with } \\
\text { mixing from agitator only. }\end{array}$ & $\mathrm{N} / \mathrm{A}$ & $\begin{array}{l}1 . \\
2 . \\
3 .\end{array}$ & $\mathrm{N} / \mathrm{A}$ \\
\hline 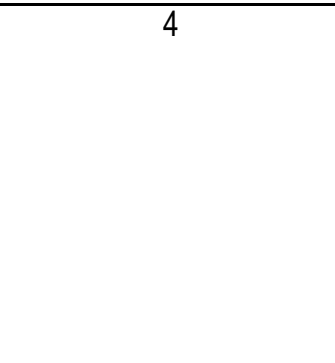 & $\begin{array}{l}1: \\
2 . \\
3 . \\
4 . \\
5 .\end{array}$ & $\begin{array}{l}1 . \\
2 . \\
3 .\end{array}$ & \\
\hline 6 & $\begin{array}{l}\text { 1: } \\
2 . \\
3 . \\
4 . \\
5 .\end{array}$ & $\begin{array}{l}1 . \\
2 . \\
3 .\end{array}$ & \\
\hline 8 & $\begin{array}{l}1: \\
2 . \\
3 . \\
4 . \\
5 .\end{array}$ & $\begin{array}{l}1 . \\
2 . \\
3 .\end{array}$ & \\
\hline 10 & $\begin{array}{l}1: \\
2 . \\
3 . \\
4 . \\
5 .\end{array}$ & $\begin{array}{l}1 . \\
2 . \\
3 .\end{array}$ & \\
\hline
\end{tabular}

Page 22 of 25 


\section{Appendix A4: Chemical Hazard Identification Summary}

\begin{tabular}{|c|c|c|c|c|c|c|c|c|c|c|c|}
\hline 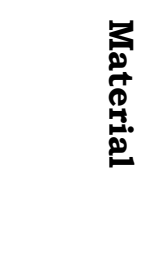 & 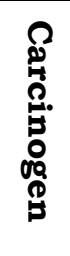 & 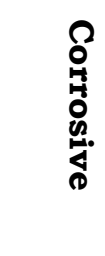 & 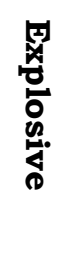 & 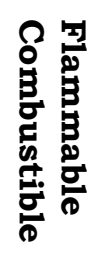 & है & 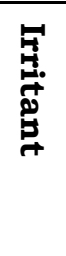 & 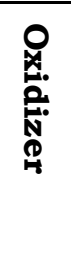 & $\begin{array}{l}\text { '0 } \\
\text { : } \\
0 \\
0 \\
0\end{array}$ & 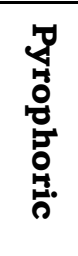 & 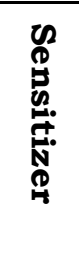 & $\begin{array}{l}0 \\
0 \\
\frac{0}{4} \\
\Xi \\
ٍ]\end{array}$ \\
\hline $\begin{array}{l}\text { Test } \\
\text { Simulant }\end{array}$ & & $\mathrm{X}$ & & & & & & & & & \\
\hline
\end{tabular}

\section{HAZARDOUS MATERIAL IDENTIFICATION}

Carcinogen - substance capable of causing or producing cancer

- Types of carcinogens: Asbestos, vinyl chloride, cadmium, benzene, formaldehyde

- Routes of entry: Inhalation, ingestion absorption, injection

- Signs and symptoms of exposure: Usually latent affects include anemia, tumors or lesions, weight loss, body abnormalities

- Target organs: Different carcinogens affect different organs. MSDS should be referenced for each material.

Corrosives - any chemical that will attack and destroy any living tissue it physically contacts

- Types of corrosives: Acids such as sulfuric, hydrochloric, perchloric, chromic and nitric. Caustics such as lime, lye (sodium hydroxide), phosphates, and chromates

- Routes of entry: Absorption, inhalation, ingestion, injection

- Signs and symptoms of exposure: Burns, destruction of tissue, dry and cracking skin. Note: Depending on exposure, these hazards can be internal and external.

- Target organs: Primarily skin, but can affect the eyes, stomach, lungs, and respiratory system.

Explosives - any material that causes a sudden (almost instantaneous) release of pressure, gas and heat when subjected to sudden shock, pressure, or high temperature

- Types of explosives: nitroglycerin, aged picric acid, aged ether, TNT

- Routes of entry: Injection, ingestion, inhalation, absorption

- Signs and symptoms of exposure: Hazards expected form accidental explosions include intense heat and light, shattering force, fire, powerful blast impacts, and fragments or projectiles

- Target organs: Any part of the body is susceptible to damage from an explosive 
Flammables and Combustibles - Any material that can ignite or produce a flame. Flammables have a flash point below $100^{\circ} \mathrm{F}$. Combustibles have a flash point at or above $100^{\circ} \mathrm{F}$.

- Types of flammables: Benzene, butane, toluene, gasoline,

- Types of combustibles: Phenol, diesel

- Routes of entry: Ingestion, inhalation, absorption, injection

- Signs and symptoms of exposure: Burns or blisters

- Target organs: Any part of the body is susceptible to damage from an explosive

Gases - a phase of matter in which the substance expands readily to fill any containing vessel. Gas has no definite volume or shape.

- Types of gases: There are four categories of gases: poisonous, flammable, irritant, and asphyxiate. Types of gases include chlorine, fluorine, hydrogen sulfide, sulfur dioxide, acetylene, butane, ethylene, ethane, methane, and propane.

- Routes of entry: Absorption through mucous membranes, eyes, skin; inhalation of toxic vapors

- Signs and symptoms of exposure: Dizziness, headache, nausea, watery eyes, difficulty breathing, frostbite

- Target organs: Lungs, skin, eyes, respiratory system

\subsection{IRRITANTS - A CHEMICAL THAT CAN CAUSE INFLAMMATION AT THE POINT OF CONTACT.}

- Types of irritants: Ammonia, fibrous glass, fine meal dusts, alcohol, solvents, and detergents

- Routes of entry: Absorption, inhalation, injection, ingestion

- Signs and symptoms of exposure: Skin, eye, and mucous membrane irritation; dermatitis; coughing; itching

- Target organs: Upper respiratory tract, eyes, skin, lungs, mouth, nose

Oxidizers - any material that can supply oxygen to start or support a fire.

- Types of oxidizers: Nitrates, hydrogen peroxide, chlorate, chlorine gas, perchloric acid

- Routes of entry: Absorption, inhalation, ingestion, injection

- Signs and symptoms of exposure: Internal and external burns and blisters

- Target organs: Skin, eyes, lungs, mucous membranes

Poisons - Substances that may cause death or serious injury if swallowed, inhaled or come in contact with the skin.

- Types of poisons: Carbon monoxide, dieldrin, arsenic pentoxide, chlorine, methylene dichloride, cyclohexanone, cyanide

- Routes of entry: Absorption, inhalation, injection, ingestion

- Signs and symptoms of exposure: Coughing, difficulty breathing, skin rash, eye irritation, unconsciousness, light-headedness, shortness of breath, choking, tightness in chest 
- Target organs: Liver, kidneys, bone marrow, muscles, lungs, central nervous system

Pyrophorics - material capable of igniting automatically when exposed to air

- Types of pyrophorics: boron, diborane, white or yellow phosphorous

- Routes of entry: Absorption, inhalation, ingestion

- Signs and symptoms of exposure: Some pyrophoric materials may break into flame when exposed to air and cause burns to the skin while others may produce an explosion

- Target organs: All parts of the body may be affected in the event of a fire or explosion

Sensitizers - material that can cause an allergic reaction. A person may work with a chemical for a period of time with no allergic reaction. However, once sensitized, the person may experience an allergic reaction after only a brief, low-level exposure to the material

- Types of sensitizers: Turpentine, isocyanates, formaldehyde, chromic acid, chromium and nickel metal, epoxy resin

- Routes of entry: Absorption, inhalation, injection, ingestion

- Signs and symptoms of exposure: Skin rash, puffy eyes, runny nose, watery eyes, coughing, sneezing

- Target organs: Skin, eyes, mucous membranes, respiratory tract

Solvent - material, usually liquid, that dissolves or can dissolve another substance.

- Types of solvents; alcohol, gasoline, diesel fuel, chlorinated hydrocarbons, benzene, methanol, carbon disulfide, acetone

- Routes of entry: Absorption, inhalation, injection, ingestion

- Signs and symptoms of exposure: Skin will appear white and dry because the natural oils have been removed. Some solvents can cause skin irritation, redness dermatitis, and itching. Some organic solvents can cause eye irritation, coughing, and respiratory arrest.

- Target organs: Skin, eyes, central nervous system, lungs, liver, heart 